\title{
Nine social indices as functions of population size or density
}

\author{
KATHRYN KELLEY \\ State University of New York, Albany, New York
}

\begin{abstract}
Population size and density effects on nine social indices were studied using United States statistics in the late 1970s. Personally violent crimes (murder, rape, and robbery) occurred more frequently with increasing population size, whereas the likelihood of nonviolent crimes (burglary, larceny) increased with lower density. The ratio of divorces to marriages decreased as population size increased. Larger populations were associated with motor vehicle theft, whereas denser ones were associated with greater public assistance. Frequency of aggressive assault was unrelated to either environmental variable. The roles of affect and degree of interpersonal involvement were suggested as possible explanations of these findings.
\end{abstract}

The press of population growth creates the need for cities of increasing size to serve multitudes of people. Catastrophes, impending doom, and/or social problems have been predicted as a result, with widespread agreement among experts that a serious situation exists and that most proposed solutions are unappealing (Toney, Stinner, \& Kim, 1981). The present study of archival data had the aim of examining naturally existing frequencies of important social behaviors in the United States with respect to two variables: population size and density. It was hypothesized that the two variables would function as joint predictors of the indices used. Research on these indices has proceeded in generally separate directions and has revealed their respective value in understanding and predicting the problems of large aggregates of human beings.

Research and theorizing on the effects of population size have often occurred at the demographic level of analyzing selected trends. From the pioneering work of Wirth (1938) to more recent findings on population size effects (e.g., Baldassare, 1979), the analysis of data on the aggregate level has indicated several general trends in this area. But as these and other authors have pointed out, such data cannot yield predictions with respect to particular cities or to specific outcomes over any period of time.

Tienda (1981) described the shifts in household structure that varied with population size changes. Preference surveys have also shown correspondence between attitudes about population size and movement to areas of lower population size than in the past (Frederickson, Heaton, Fuguitt, \& Zuiches, 1980). Research has shown that as television programs have allowed individuals to become more aware of inequities between themselves and ever larger groups of people, frequency of larcenous crime has increased (Hennigan, Del Rosario, Health, Cook, Whar-

The author's mailing address is: Department of Psychology, State University of New York at Albany, Albany, NY 12222. ton, \& Calder, 1982). Other findings show the usually negative impact of growth in size on employment and income (Easterlin, 1980), corporate efficiency and success (von Hoffman, 1981), and other areas of personal welfare (Epstein, 1981).

In contrast with the demographic emphasis by population experts, studies of density, crowding, and personal space have usually involved experimental analyses of situations varying in one or more related factors. One notable exception in Preuss's (1981) study of density and urbanness as negative correlates of voter turnout. The quality of individuals' lives changes with increasing population density (Severy, 1979), generally in a negative direction in studies of stress (Walden \& Forsyth, 1981), norm violation (Thalhofer, 1980), aggression (Freedman, 1975), and altruism (Latane \& Darley, 1970). Of course, density is partially independent of a perception of crowdedness. Increased crowding apparently heightens arousal levels that may be interpreted with positive or negative affective labeling (Knowles, 1979).

Many models exist to explain the effects of size and density (e.g., Sadalla, Burroughs, \& Staplin, 1978). They generally agree that affect determines the perception of stimuli and some portion of resultant behavior. With positive labeling, for example, prosocial effects of greater density can sometimes be observed (e.g., Freedman, Birsky, $\&$ Cavoukian, 1980). Of course, current psychological theorizing and research results argue that the perception of density influences stress-related behaviors through the development of negative affect (Baum, Singer, \& Baum, 1981). An error commonly occurs in current experimental research that disguises the two variables' independent contributions: the manipulation of density solely by changing numbers of people but not the size of the observed area. Some researchers have recognized this problem (e.g., Leventhal \& Levitt, 1979).

Despite the bifurcation in strategy for the attainment of scientific knowledge, and with strong indications that both population size and density influence several forms 
of social behavior, this study was undertaken to examine their relative and possible joint contributions.

\section{METHOD}

Data were obtained from the most recently available versions of two sources. The F.B.I. Uniform Crime Reports: Crime in the United States, 1979 (U.S. Department of Justice, 1979) provided population size, land area, and frequency listings for cities with respect to the following crimes: murder, aggravated assault, burglary, larceny-theft, and motor vehicle theft. Land area, divorce and marriage numbers, and amount of public assistance to families with dependent children were obtained from the City and County Data Book, 1977: A Statistical Abstract Supplement (U.S. Department of the Census, 1977). Complete data for all indices existed in these sources for the 175 cities that were used as data points in this study.

\section{RESULTS}

\section{Size and Density Effects}

Tables 1 and 2 list the cutoff points for four levels of population size and three levels of density, respectively. Cutoff points were chosen to create equality in cell sizes. Squared Pearson correlations showed 7\% common variance between population and land area and $15 \%$ between population and density. These points were chosen to maximize the number of levels for each variable while maintaining a sufficient number of observations to allow additional analyses. Each raw data point for the social indices listed in Tables 1 and 2 was subjected to a transformation of 100,000/population size. As noted in Table 1, the frequencies of divorce and marriage were converted to a ratio of the first to the second. Nine analyses of variance were computed using a 4 (population size) $\times 3$ (density) design for each of the nine social indices. Multivariate analyses of variance revealed no significant effects of population size or density. Using public assistance figures as an indicant of income levels, analyses of covariance did not support the alternative explanation (Freedman, Heshka, \& Levy, 1975) that personal poverty or wealth mediated the relationships reported in Tables 1 and 2 . Such findings are consistent with those of Sale (1978). In addition, none of the present results varied with two methods of transformations using logs or exponential reciprocals.

Analyses on the variables showed the five significant main effects of population size listed in Table 1, the three for density in Table 2, and no interactions. Differences between relevant groups were tested via the Duncan procedure. Finally, the Tables 1 and 2 list partial correlations for each index, with either population size or density held constant.

\section{DISCUSSION}

In a comparison of relationships among population size and density with nine social indices, these results supported their relatively independent contribution to variations in social behavior. As shown in Tables 1 and 2, significant differences between respective partial correlations occurred only in conjunction with population size and not with density effects.

Why did some indices vary mainly with population size, and others with density? In several instances, interpersonal violence used during the commission of a crime seems to differentiate these results. For example, the violent crimes of murder, rape, and robbery all increased in frequency with greater population size. One could speculate that, as population size increases, the likelihood of incidents eliciting negative affect correspondingly rises in frequency (e.g., information overload, waiting in line, competition for resources, etc.). If so, interpersonal aggression in various forms would be expected to increase accordingly (Baron, 1977). In contrast, the interpersonally nonviolent and less affectively negative crimes of burglary and larceny occur more commonly with lower social density. Therefore, it appears that violence against persons can be predicted to accompany crime in large population areas. In sparsely settled areas, nonviolent crimes occur more frequently in relative terms. Such crimes seem to be motivated by monetary needs

Table 1

Social Indices Varying Significantly with Population Size

\begin{tabular}{|c|c|c|c|c|c|}
\hline \multirow[b]{2}{*}{ Population Size } & \multicolumn{5}{|c|}{ Social Index ${ }^{a}$} \\
\hline & Murder & Rape & Robbery & Car Theft & Divorce/Marriage \\
\hline \multicolumn{6}{|c|}{ Means $^{b}$} \\
\hline $\begin{array}{c}65,000-137,000 \\
137,001-263,000 \\
263,001-560,000 \\
560,001-9,500,000\end{array}$ & $\begin{array}{l}3.94 \mathrm{a} \\
4.78 \mathrm{a} \\
5.41_{\mathrm{a}} \\
8.48 \mathrm{~b}\end{array}$ & $\begin{array}{l}21.62_{\mathrm{c}} \\
21.86_{\mathrm{c}} \\
22.65_{\mathrm{c}} \\
30.69_{\mathrm{d}}\end{array}$ & $\begin{array}{r}67.62_{\mathrm{e}} \\
91.40_{\mathrm{e}} \\
123.00_{\mathrm{e}} \\
208.92_{\mathrm{f}}\end{array}$ & $\begin{array}{l}226.12_{\mathrm{g}} \\
209.85_{\mathrm{g}} \\
265.86_{\mathrm{g}} \\
390.32_{\mathrm{h}}\end{array}$ & $\begin{array}{l}.49_{\mathrm{i}} \\
.29_{\mathrm{j}} \\
.15_{\mathrm{k}} \\
.05_{\mathrm{l}}\end{array}$ \\
\hline $\mathrm{F}(3,163)$ & $5.95 * *$ & $3.65^{*}$ & $9.97 * *$ & $5.37 * *$ & $66.70 * *$ \\
\hline \multicolumn{6}{|c|}{ Partial Correlations ${ }^{c}$} \\
\hline $\begin{array}{l}\text { Density } \\
\text { Population Size }\end{array}$ & $\begin{array}{c}-.01 \\
\triangle \\
.35 * *\end{array}$ & $\begin{array}{c}-.06 \\
\nabla \\
-.18 * *\end{array}$ & $\begin{array}{l}.20^{* *} \\
.55^{* *}\end{array}$ & $\begin{array}{l}.18^{* *} \\
.27^{* *}\end{array}$ & $\begin{array}{l}-.04 \\
\nabla \\
-.37 * *\end{array}$ \\
\hline
\end{tabular}


Table 2

Social Indices Varying Significantly with Density

\begin{tabular}{lccc}
\hline & \multicolumn{3}{c}{ Social Index $^{\mathrm{a}}$} \\
\cline { 2 - 4 } Density & Public Assistance & Burglary & Larceny \\
\hline \multicolumn{4}{c}{ Means $^{\mathrm{b}}$} \\
$23-149$ & $3860.74_{\mathrm{m}}$ & $1043.20_{\mathrm{p}}$ & $2463.15_{\mathrm{r}}$ \\
$150-270$ & $4004.96_{\mathrm{m}}$ & $932.64_{\mathrm{op}}$ & $894.95_{\mathrm{qr}}$ \\
$271-8210$ & $5368.78_{\mathrm{n}}$ & $894.95_{\mathrm{o}}$ & $1772.93_{\mathrm{q}}$ \\
$\mathrm{F}(3,163)$ & $3.19^{*}$ & $3.05^{*}$ & $3.48^{*}$ \\
& Partial Correlations $^{\mathrm{c}}$ & \\
Population Size & $.19^{* *}$ & .01 & -.06 \\
Density & $.26^{* *}$ & $-.16^{*}$ & $-.15^{*}$ \\
\hline
\end{tabular}

${ }^{a}$ Each social index for a given city consisted of: (number of incidents $\times 100,000) / p o p u l a t i o n$ size. $\quad{ }^{b}$ Within each social index, means with different subscripts differ significantly $(p<.05)$ by the Duncan procedure. $\quad{ }^{\mathrm{C}}$ Partial correlations with population size held density constant, and partial correlations with density held population size constant. There were no significant differences between partial correlations for each index. $\quad{ }^{*} p<.05 . \quad{ }^{* *} p<.01$.

rather than by hostility. As population density decreases, the perceived odds of not being caught may increase. For example, a potential burglar might prefer entering widely separated houses in semirural areas to entering houses in the densely packed neighborhoods of a large city.

Surprisingly, the ratio of divorces to marriages decreased with greater population size, and significant differences were observed between size levels. Smaller cities were more often the sites of divorces than the sites of marriages. At least in the area of personal happiness and intimate relationships, small populations may offer inadequate sources of stimulation and activity (Proshansky, 1976). With the greater variety present in highly populated cities, the stability and constancy of a personal relationship may become more valuable as a means of controlling information overload (Milgram, 1977). The United States' high rate of divorce and practice of serial monogamy may thus partially be a by-product of boredom in an unstimulating environment. It is also possible that people of marriageable age (e.g., young adults) are more likely to live in large cities, but with financial success, they move to smaller towns, where they get divorced.

Three remaining indices evinced varying degrees of relationship to the variables of interest, and hypotheses are suggested for further testing. Public assistance to families with dependent children was elevated in denser areas, where poverty and joblessness concentrate the need for attention as well as the improbability of improvement. Second, larger population centers, of course, include more automobiles and thus face greater threat of their theft (and less chance of their recovery) than is true for smaller cities. The one index studied that was unrelated to either size or density was aggressive assault. This crime most often takes the form of mugging, which has neither the characteristics of a totally impersonal crime nor those of one involving a personal relationship. Such behavior expresses both financial need and interpersonal hostility and apparently differs from those behaviors that fit only one such category.

Data presented in behalf of the various models on size and density effects are inconsistent with respect to the nature of links between crowding and density. These data indicate that size and density are related to different social indices, in both positive and negative directions. The absence of some typical effects in these archival observations should alert theorists to the inadequacy of predictions from theories on this topic, and to the realization of the possible independence of relationships shown in the laboratory from ones drawn from a naturally existing source. Nonetheless, alternative theoretical explanations were suggested for the contrary findings, primarily on the basis of direction of affect and level of interpersonal involvement.

\section{REFERENCES}

BALDASSARE, M. (1979). Residential crowding in urban America. Berkeley, CA: University of California Press.

Baron, R. A. (1977). Human aggression. New York: Plenum.

Baum, A., Singer, J. E., \& Baum, C. S. (1981). Stress and the environment. Journal of Social Issues, 37, 4-35.

EASTERLIN, R. A. (1980). Birth and fortune: The impact of numbers on personal welfare. New York: Basic Books.

Epstein, Y. M. (1981). Crowding, stress, and human behavior. Journal of Social Issues, 7, 126-144.

Frederickson, C., Heaton, T. B., Fuguitt, G. V., \& Zuiches, J. J. (1980). Population and Environment, 3, 280-297.

Freedman, J. L. (1975). Crowding and behavior. New York: Viking Press.

Freedman, J. L., Birsky, J., \& Cavoukian, A. (1980). Environmental determinants of behavioral contagion: Density and number. Basic and Applied Social Psychology, 1, 155-161.

Freedman, J. L., HeshKa, S., \& Levy, A. (1975). Population density and pathology: Is there a relationship? Journal of Experimental Social Psychology, 11, 539-552.

Hennigan, K. M., Del Rosario, M. L., Health, L., Cook, T. D., Wharton, J. D., \& Calder, B. J. (1982). Impact of the introduction of television on crime in the United States: Empirical findings and theoretical implications. Journal of Personality and Social Psychology, 42, 461-477.

KNOWLES, E. (1979). The proximity of others: A critique of crowding research and integration with the social sciences. Journal of Population, 2, 3-17.

LATANe, B., \& DaRley, J. M. (1970). The unresponsive bystander: Why doesn't he help? New York: Appleton.

Leventhal, G., \& LevitT, L. (1979). Physical, social, and personal factors in the perception of crowding. Journal of Nonverbal Behavior, 4, 40-55.

Milgram, S. (1977). The individual in a social world. Reading, MA: Addison-Wesley.

Preuss, G. G. (1981). The effects of density and urban residence on voter turnout. Population and Environment, 4, 246-265.

Proshansky, H. (1976, September). City and self identity. Paper presented at the meeting of the American Psychological Association, Washington, DC.

Sadalla, E. K., Burroughs, W. J., \& Staplin, L. J. (1978). The experience of crowding. Personality and Social Psychology Bulletin, 4, 304-308.

SALE, K. (1978). The polis perplexity: An inquiry into the size of cities. Working Papers for a New Society, 6, 64-77.

Severy, L. (Ed.). (1979). Crowding. New York: Human Sciences Press.

THALHOFER, N. N. (1980). Violation of a spacing norm in high social density. Journal of Applied Social Psychology, 10, 175-183.

TIENDA, M. (1981). Macro and micro contexts of dependency rates: An illustration with Peruvian data. Population and Environment, 4 , 79-96.

Toney, M. B., Stinner, W. F., \& Kim, Y. (1981). The population debate: A survey of opinions of a professional organization's membership. Population and Environment, 4, 156-173.

U.S. DePartment OF THE Census. (1977). City and county data book, 1977: A statistical abstract supplement. Washington, DC: U.S. Government Printing Office.

U.S. DePARTMENT OF JuSTICE. (1979). The F.B.I. uniform crime reports: Crime in the United States, 1979. Washington, DC: U.S. Government Printing Office.

Von Hoffman, N. (1981). Playing monopoly. New Republic, 185(8\&9), 11-12.

WALDEN, T. A., \& Forsyth, D. R. (1981). Close encounters of the stressful kind: Affective, physiological, and behavioral reactions to the experience of crowding. Journal of Nonverbal Behavior, 6, 46-64.

WIRTH, L. (1938). Urbanism as a way of life. American Journal of Sociology, 44, 1-24. 